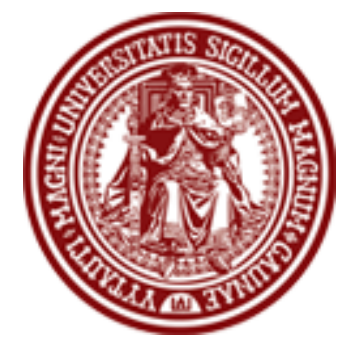

DE DE GRUYTER OPEN

\section{BALTIC JOURNAL OF LAW \& POLITICS}

A Journal of Vytautas Magnus University

VOLUME 10, NUMBER 1 (2017)

ISSN 2029-0454

\title{
FACTORS THAT INFLUENCE PAROLE BOARDS' AND JUDGES' DECISIONS ON PAROLE APPLICATION IN LITHUANIA
}

\author{
Ilona Michailovič \\ Senior Research Fellow, Dr. \\ Law Institute of Lithuania, Criminological Research Department (Lithuania) \\ Contact information \\ Address: Ankštoji str. 1A, LT-01109 Vilnius, Lithuania \\ Phone: +370 52497596 \\ E-mail address: ilona.michailovic@teise.org
}

\section{Liubovè Jarutiené}

\author{
Junior Research Fellow \\ Law Institute of Lithuania, Criminological Research Department (Lithuania) \\ Contact information \\ Address: Ankštoji str. 1A, LT-01109 Vilnius, Lithuania \\ Phone: +370 52497591 \\ E-mail address: liubove.jarutiene@teise.org
}

Received: April 3, 2017; reviews: 2; accepted: June 29, 2017.

\section{ABSTRACT}

This article examines problems of parole application in Lithuania. The research applies a qualitative study in order to learn the peculiarities of the work and decision-making of judges and parole boards. Additionally, this study analyzes social research reports, filled out by staff in correctional facilities. This study covers as many factors influencing parole application as possible, and takes into account the peculiarities of the particular parole stages. Conclusions of this study should help theorists and practitioners see parole 
application from the point of view of judges and parole board members. Moreover, this work should encourage dialogue between judges, prison staff and community members not only in Lithuania, but, also in other countries.

\section{KEYWORDS}

Parole, social research report, legal factors of parole decision making, extralegal factors of parole decision making 


\section{INTRODUCTION}

Recently the parole system in Lithuania has undergone several reforms. Fundamental changes were made in 2003 with the enactment of the Penal Enforcement Code (hereafter - PEC) ${ }^{1}$, and in 2012, when the special section of the PEC regulating parole procedure and Probation $\mathrm{Act}^{2}$ came into force. Furthermore, in 2012 parole boards were established in order to evaluate personal features of parole seeking inmates, as well as to examine the progress inmates made in prison and their readiness for reentry. Also, according to the new parole regulation, parole boards had to recommend the duties and special measures suitable for each inmate during parole period. ${ }^{3}$ On June 14, 2012, the Minister of Justice affirmed the application of social research reports ${ }^{4}$, designed in order to characterize inmates who seek parole. A two-stage parole system was established in Lithuania, since parole boards were given power to make decisions, which must be reviewed in court in order to be approved or rejected. Finally, the latest parole regulation changes were made in September $2015^{5}$, in an attempt to set up more favorable conditions of parole application and ensure more effective process of parolee's rehabilitation and integration.

Although parole is promoted by penal law professionals, and emphasized in international recommendations, the Probation Act and penal legislation, recent statistics show the decline of parole application in court practice. Analysis of court practice in parole cases reveals that courts are often inconsistent about the criteria of parole application, so the same criteria may be interpreted unequally. ${ }^{6}$

Recent changes of parole regulation should have made parole application more common, but lately the percentage of paroled persons has been decreasing. For instance, in 2008-2010 the proportion of paroled inmates reached 50 percent, in 2011 it dropped to 40 percent, and starting from 2012 the proportion of paroled

\footnotetext{
1 Penal Enforcement Code of the Republic of Lithuania, Official Gazette (2002, no. 73-3084).

2 Law on Changes of the 18, 19, 66, 90,91,126, 138, 140,152,154,157, 158, 159, 164, 176 Articles and invalidation of the 127, 160, 161, 162, 163, 179 Articles of Penal Enforcement Code of the Republic of Lithuania, Official Gazette (2012, no. 4-110); Law of Changes of the 11, 17, 18, 21, 25, 30 and 31 Articles of Probation Act of the Republic of Lithuania, Register of Legal Acts (2015, no. 11079).

3 In order to draw the public into the process of inmates' rehabilitation and refuse subjective procedure of decision-making about parole application, Article 164 of the Lithuanian PEC states that parole boards are formed by the Prison Department under the Ministry of Justice of the Republic of Lithuania in order to make decisions on inmates' requests to apply parole.

${ }^{4}$ For more information see the Order of the Minister of Justice of the Republic of Lithuania on the Approval of the Form of Social Research Report and Methodical Recommendations for the Preparation of Social Research Report, Official Gazette (2012, no. 68-3500).

${ }^{5}$ Law on Changes of the Penal Enforcement Code of the Republic of Lithuania, Register of Legal Acts (2015, no. 11069).

6 Andželika Vosyliūtè, "Lygtinio paleidimo iš pataisos istaigu taikymo teismu praktikoje probleminiai aspektai" (Problematic aspects of parole application in court practice); in: Gintaras Švedas, ed., Bausmiu vykdymo sistemos teisinis reguliavimas ir perspektyvos Lietuvos Respublikoje (Legal regulation and perspectives of penal system in Lithuania) (Vilnius: Prison Department under the Ministry of Justice of the Republic of Lithuania, 2010).
} 
persons has been gradually decreasing each year (37 percent in 2012, 34 percent in 2013, 31 percent in 2014 and 33 percent in 2015) ${ }^{7}$.

According to the data provided by the Prison Department under the Ministry of Justice of the Republic of Lithuania, from July 2012 to April 2014 parole boards had 6252 parole hearings, and in about half of the instances ( 55.6 percent) inmates were granted parole. However, only half of parole boards' decisions were approved in court, consequently only 30 percent of inmates were granted parole. Therefore, regarding parole statistics after changes of parole regulation in July 2012, parole application has become less popular, since courts approve only a half of parole requests, which have been approved in parole boards. Also, parole boards tend to approve only about a half of all parole requests.

Considering existing parole application issues, the purpose of this study was to identify the factors that may influence parole decision-making in parole boards and courts. The study is based on interviews with parole board members and judges, and also on the content analysis of social research reports about parole seeking inmates. In the course of the study we defined legal and extralegal factors that may influence parole decision-making. Legal factors include formal criteria of parole application, set in the PEC, whereas extralegal factors include other subjective information that may be important to parole board members or judges. Also, the study revealed some other specific factors that may affect judges' parole decision-making. In general, we cover as many relevant decision-making factors as possible in order to reveal the peculiarities of particular parole stages.

Lithuanian and foreign scholars usually choose particular aspects of parole for academic analysis. As far as we know, the latest changes of PEC section regulating parole were made in September 2015, so it is critical to analyse parole application practice after the recent changes. The results of this study should help us find reasonable solutions to existing parole application problems. ${ }^{8}$

\section{METHODS}

The $1^{\text {st }}$ and $2^{\text {nd }}$ parts of the study: the analysis of interviews with parole board members and judges

Sample. Regarding the complexity of reaching parole board members, we chose a convenience sampling procedure. 8 Parole board members from 49 different prisons participated in the $1^{\text {st }}$ part of the study. As participants were

\footnotetext{
${ }^{7}$ Report of the Supervision Unit of the Prison Department under the Ministry of Justice of the Republic of Lithuania on Parole Process and Parole Boards' and Courts's Motives of Parole Declination in Year 2015, March $14^{\text {th }}, 2016$, no. LV-948, sec. 1.

8 Authors would like to thank students of Forensic psychology course in Vilnius University Faculty of Phylosophy Violeta Cimalanskaitè, Ligita Černiauskaitè and Asta Masiulionytè for their assistance during the study.

9 It should be noted that all in all there are 9 prison facilities in Lithuania, where parole can be applied.
} 
working in various correctional facilities, we had the opportunity to interview the specialists working with both male and female inmates as well as inmates from various regions of Lithuania. 4 participants were working in prison, the rest were delegated by other public institutions. 4 of the interviewed parole board members were male, 4 of them were female. According to the Regulations of parole board, there should be at least 7 members in each board, so there should be at least 63 parole board members in all Lithuanian prison facilities. However, the exact number of parole board members in Lithuanian prison facilities is unknown as it has not been announced officially. It would be difficult to estimate what percentage of all parole board members were interviewed during this study, yet we tried to reach the participants from various regions in order to collect representative data.

7 judges who have recently been working on parole cases participated in the $2^{\text {nd }}$ part of the study ( 3 of them were female, 4 were male). 2 interviewed judges were working in regional courts, while the other 5 were working in district courts. In Lithuania parole hearings take place in 6 district courts and 3 regional courts, so the sample was compiled to cover the opinion of judges working in various regions and court instances. During the $2^{\text {nd }}$ part of study we also applied convenience sampling procedure. The judges who were asked to participate in the study had to meet a criterion of working on parole cases from January 2015 to March 2016, when the study was conducted. This criterion was applied to cover parole application practice before the recent changes in parole regulation and after these changes were made.

Research methods. We used structured interviews to reveal parole board members' and judges' attitudes towards parole and discover presumable motives of parole declination. Questions were formulated particularly for each part of the study, with respect to specific functions of parole boards and courts during parole application process. Also, some interview questions were formulated according to the latest legislation, regulating different parole stages.

Research procedure. Interviews with parole board members and judges were performed in March 2016; all the interviews took place in a calm setting; one of the interviews was performed on the phone. Each interview was recorded and transcribed later. Afterwards interview transcriptions were analysed applying qualitative content analysis. In the course of analysis we used a semantic approach, concentrating on explicit meanings discovered in the research data.

3rd part of the study: the analysis of social research reports about inmates, who tried to seek parole

Data. For this study 28 social research reports about inmates, who tried to seek parole, were obtained from the Prison Department under the Ministry of 
Justice. The reports had been prepared in various correctional facilities around Lithuania after the latest changes of PEC in September $2015 .{ }^{10}$ As this study aimed at analyzing motives of parole declination, we requested only the reports for the cases when inmates were not granted parole.

The decision to analyze social research reports was made because of the importance of reports for decision-making during both stages of parole. Social research reports uncover social and psychological characteristics of inmates, their risk of recidivism, criminogenic needs and progress inmates made in prison. Also, social research reports contains individualised recommendations on the parole conditions suitable in each case. It might be assumed that social research reports partly shape the parole board member's and judges' opinion about the inmates who seek parole, because, according to the Code of Criminal Procedure, the parties do not arrive at parole hearings in court. Moreover, according to the Parole Boards Rules $^{11}$, board members are not obliged to invite inmates to the hearings, thus a parole decision can be often made in their absence. The content analysis of social research reports will contribute to uncovering the information on the basis of which parole board members and judges make parole decisions.

Research methods. The research applies a qualitative thematic analysis ${ }^{12}$ to analyse social research reports. Moreover, we stuck to the semantic approach, focusing on explicit meanings discovered in the research data.

Research procedure. The content analysis was conducted in March and April 2016. First, the social research reports were carefully read several times, the research relevant information was marked in the text, and initial codes were generated. Then, the codes were grouped into broader subcategories that were relevant to the primary research topic and were found in the majority of analysed reports. The subcategories were titled according to their content. After that, subcategories that were found in the data were gathered into wider categories, and the categories were carefully reviewed. Finally, the categories found in the data were assigned to wider themes; the themes were also reviewed before the final report.

106 social research reports were obtained from Marijampole correctional facility, 6 were from Vilnius correctional facility, 6 were from Alytus correctional facility, 5 were recieved from Kybartai correctional facility, 4 were from Panevezys correctional facility and 1 was obtained from Pravieniskes correctional facility.

${ }_{11}$ Order of Minister of Justice of the Republic of Lithuania No 1R-154 on Confirmation of Parole Boards Rules, Official Gazette (2012, no. 65-3314).

12 For more information see Virginia Braun and Victoria Clarke, "Using thematic analysis in psychology," Qualitative research in psychology 3 (2) (2006). 


\section{LEGAL FACTORS OF PAROLE DECISION-MAKING}

Since parole board members and judges should primarily rely on PEC during parole hearings, it was essential to examine the role of legal basis formulated in Article 157 of the PEC during parole decision-making process.

\subsection{IMPLEMENTATION OF MEASURES SET IN INDIVIDUAL SOCIAL REHABILITATION PLAN}

Regarding the requirement to implement measures set in the individual social rehabilitation plan, parole board members emphasized that this criterion is quite significant during parole decision-making process (e. g. P5: "If it's not being fulfilled, we take it as a great drawback", P6: "If a person is not trying to fulfill the rehabilitation plan, he is not actually trying to change himself"). However, according to some board members, fulfillment of the plan is not always taken into account, because board members usually are not introduced with the plan (e. $\mathrm{g}$. P7: "Usually we do not have a chance to look over that social rehabilitation plan").

Regarding the requirement to implement the measures set in the social rehabilitation plan, the judges stated that this criterion is important during the parole decision-making process, but it is not considered to be crucial (e. g. J5 "Well, he may seem to try to fulfill the plan, but this formal criterion is not enough to apply parole ..."). Judges also mentioned some drawbacks of individual social rehabilitation plans (e. g. J7: "Sometimes we hear inmates saying, that it is rather formal document. If it's true, that it's sad indeed. I mean attending rehabilitation programs ..."). Thus the implementation of measures set in individual social rehabilitation plan is an important criterion for parole applications, but it is not considered to be crucial. Judges noticed some imperfections of social rehabilitation plans, which may negatively affect the inmates' rehabilitation process.

According to the findings of this study, the members of parole boards consider the implementation of measures set in individual social rehabilitation plan to be an important factor of parole application. Judges also believe it to be quite important, but it is not assigned to the crucial factors during parole hearings in court. Therefore, research findings reveal some differences between boards members' and judges' opinions about the importance of legal parole application criteria.

\subsection{LEVEL OF CRIMINAL RISK}

Paragraph 1 of Article 157 of the PEC also mentions another criterion for parole application, according to which inmates who seek parole should raise low 
criminal risk and (or) their progress of risk reduction should create a presumption that inmates shall comply with the law and shall not commit any crime.

Research data analysis shows that level or criminal risk is highly important for parole decision-making. The interviewed parole board members claimed that it is easier to make a decision when the person is classified as low-risk. Also, board members thought the decrease of criminal risk level to be important. On the other hand, a few board members questioned the reliability of criminal risk estimation (e. g. P4: "Being low-risk does not predict the future, it only shows us present situation"; P3: "Sometimes I form a better opinion about him or it is opposite to that coefficient"). Considering the level of criminal risk during the parole application process, some parole board members noted that parole application also depends on the type of correctional facility. In those facilities, where inmates serve their first sentence, criminal risk should be low in order to apply parole. However, in those facilities where inmates are imprisoned repeatedly, parole may be applied to inmates who were classified as moderate-risk.

In the course of the study we also tried to find out how judges who make a final parole decision interpret and apply the legal criterion discussed above. Regarding the significance of criminal risk level during parole decision-making, the majority of interviewed judges were convinced that inmates who may be granted parole should be classified as low-risk (e. g. J1: "That level of criminal risk should be low"; J3: "Still, legislators presumed that the risk should be low, let's say, most of them should be classified as low-risk"). So the results show that during parole hearings in court low-risk inmates could have better chances to be paroled. Otherwise, when a person who is seeking parole is rated as moderate-risk, the interviewed judges thought that the progress of risk reduction becomes a criterion of a great importance.

In the course of social research report analysis, we were trying to find out how the criminal risk level is estimated in correctional facilities. Speaking of the criminal risk level of those who were not granted parole, it should be noted that the risk score ranged from 29 to 125 OASys points. This result signifies a great gap between inmates of the lowest and highest risk, which is 96 OASys points. It should also be noted that some social research reports did not contain numeric criminal risk score, specifying only the level of criminal risk (low, moderate or high). In the case of specifying only the level of criminal risk, parole boards and courts are provided with rather scarce information about inmates, who seek parole. For instance, if the criminal risk level is moderate, the numeric score can range from 41 to 99 OASys points, so specifying only the level of risk may induce subjective 
interpretations, which may complicate parole decision-making during both parole stages.

According to the data from social research reports, the majority of inmates who were not granted parole were classified as moderate-risk (the number of OASys points ranged from 49 to 99). It should also be noted that four social research reports contained the information about changes in risk assessment result, comparing it to the previous result. However, that kind of information was quite rare, although it could be extremely useful for parole board members and judges. Generally, the results of this study show that judges tend to apply parole when inmates are classified as low-risk, while parole board members tend to be more flexible when it comes to criminal risk level, as they tend to apply parole for both low-risk and moderate-risk groups.

Aside from the numeric OASys score, the level of criminal risk and specific difficulties are also indicated analysing criminogenic and protective factors exposed by inmates. Criminogenic factors were listed in all twenty-eight social research reports. Only in one report were static and dynamic criminogenic factors listed separately. Also, only in one report did specialists indicate the amount of OASys points determined by static and dynamic factors (SRR13). Inmates' criminal history (i. e. previous offences, violent offences, early age of firs offence, probation and parole violations, prevalence of certain offence pattern) was regarded as a criminogenic factor in twenty one reports. It should be noted that static criminogenic factors are the ones that cannot be changed over time. Stressing these factors might draw judges' and board members' attention to inmates' past (i.e. number of previous convictions, age of first offence, severity of offence committed). So it would be reasonable to emphasize the invariability of these factors in social research report. Also, it could be useful to mark the number of OASys points accumulated due to the existence of static criminogenic factors.

Scientists often note that behavior prediction is often built on past events and facts. In the case of inmates it is often built on their past social and legal difficulties, which are captured in their personal files and observed during incarceration. This circumstance inevitably leads to systematic risk overestimation. However, an "improper past" (i. e. criminal recidivism, substance use problems, long-term unemployment etc.) should not be considered the prophet of an "improper future"13.

Still, various dynamic criminogenic factors were listed more often than the static ones. Inmates' lifestyle and friends were regarded as a criminogenic factor in

\footnotetext{
13 Gintautas Sakalauskas, "Lygtinis paleidimas iš ikalinimo istaigu isigaliojus Probacijos istatymui: teorija ir praktika" (Parole application after the enactment of Probation act: theory and practice), Teises problemos 4 (82) (2013).
} 
twenty-seven cases, which meant improper friends, being influenced by bad company, illegal activity. Reasoning and conduct difficulties (such as impulsivity, aggression and self-control issues, ignoring problems, making the same mistakes) were indicated in seventeen social research reports. Substance abuse was mentioned in thirteen reports, while finance management and lack of legal income were mentioned in ten reports. Lack of vocational skills and employment was mentioned in eight reports, while procriminal attitudes were mentioned in seven cases, lack of positive social ties was mentioned in three reports.

Apart from static and dynamic criminogenic factors, it is worth noting the protective factors mentioned in reports. The analysis of social research reports shows that protective factors, which may prevent criminal behavior, are given less attention than criminogenic ones. Only seven of the twenty eight social research reports contained information about protective factors. ${ }^{14} \mathrm{~A}$ deeper analysis of the protective factors mentioned in the reports shows that having stable accommodation and proper living conditions were mentioned in four reports (e. g. SRR23, SRR25), proper vocational skills and employment opportunities (e. g. efforts to gain higher education or profession mentioned in SRR11, positive attitude towards employment, working in correctional facility) were mentioned in four cases. Absence of substance use problems or strong motivation to give up substance use were mentioned in four reports (e. g. SRR16, SRR22), while strong social ties with family members or other significant persons were mentioned in tree cases (e. $\mathrm{g}$. SRR19, SRR22). Other protective factors mentioned in social research reports included participation in correctional programs, absence of discriminatory attitudes (e. g. SRR19, SRR24, SRR25). The analysis of the social research reports about inmates who were not granted parole shows that a wide group of inmates seeking parole might be characterised with the same protective factors mentioned in reports (e. g. working or studying in correctional facility, having stable accommodation, strong social ties). Thus, information about protective factors might be insufficiently individualised. Finally, as protective factors were mentioned less often in comparison to the criminogenic ones, parole decision-making might be influenced by the negative information about inmates, rather than positive. This circumstance might make parole board members and judges cautious about parole application. According to the main principles of parole institutions, "parole decisions should be made as liberally, as it is possible, considering public safety and risk of

14 Protective factors were described in one report obtained from Pravieniskes correctional facility, two reports from Marijampole correctional facility and four reports from Panevezys correctional facility. 
recidivism. The necessity to combine multiple interest shows the difficulty of parole decision-making process"15.

\subsection{THE PROGRESS OF RISK REDUCTION}

Article 157 of PEC does not specify how the progress of risk reduction should be estimated, so the participants of this study were asked some questions about how they interpret the progress in their everyday practice.

The majority of interviewed parole board members saw participation in rehabilitation programs as a sign progress of criminal risk reduction (e. g. P4: "Inmates should complete some kind of correctional program, because their conduct is often does not match the social norms."). Also, four of eight parole board members spoke of the acquisition of vocational skills (e. g. studying in high school or gaining profession). Proper conduct during the incarceration was also considered a progress of risk reduction. In other words, considering inmates' progress, some parole board members were concerned if parole seeking inmates had ever been punished for any kind of regime violations. It should be noted that in some correctional facilities parole board members regard valid penalties as well as invalid ones. When in care the person was repeatedly seeking parole, only valid penalties were considered (e. g. P2: "When it's his first parole attempt, we consider penalties during entire incarceration period, valid as well as invalid ones. Yet we consider only valid penalties during following parole hearings").

Being employed during incarceration or seeking employment, as well as decreasing number of criminal risk points, following recommendations from the previous parole hearings and relations with family members, were also considered to signify a progress of risk reduction (e. g. P5: "Communication with other people, co-workers, also, general response to any kind of supervision"). Some parole board members also thought that changes of inmate's views of himself and others signify the progress (e. g. P4: "Inmate has to change his attitude toward family, work, politics and himself"). So, results show that progress of risk reduction is seen and interpreted rather differently during parole board hearings.

The analysis of interviews with judges showed that progress of risk reduction could be defined rather differently in court (e. g. J5: "Let's say, it was 79 points, but shifted to 63 points, then it's obvious"; J2: "We usually consider the risk, also, the things that were accomplished over some time, such as finding a job, studying ..."; J1: "I think that behavior is probably the main indicator. ... Finding a

\footnotetext{
15 Renée Gobeil nd Ralph C. Serin, "Preliminary evidence of adaptive decision making techniques used by parole board members," International Journal of Forensic Mental Health 8.2 (September 2009) // DOI: $10.1080 / 14999010903199258$.
} 
job, working. Also, the rewards for proper behavior ..."; J6: "Actually, it's quite subjective. I've already mentioned some criteria, such as paying debts, making a family, studying, seeking employment").

Some judges we interviewed interpret the progress as a significant drop of numeric OASys score. Interviewed judges claimed that they often regard the numeric OASys score, while the instrument itself and the criminogenic factors distinguished are given less attention in judges' daily practice (e. g. J7: "All we know is taken from social research report. I did not inquire additional information ..."; J2: " ... I cannot answer this question. I did not delve deeper into this"). As some of the judges who make parole decisions possibly did not study OASys instrument in detail, their expectations of the possibility to decrease criminal risk in a correctional facility might not match the real possibilities of risk reduction. In other words, it can be difficult to reduce a criminal risk score more than ten points, as inmates may not have an opportunity to work, pay debts, create a family, find accommodation outside correctional facility. Thus, interpreting progress as a significant drop of numeric OASys score may prevent some inmates from being granted parole.

Considering possible interpretations of inmates' progress, it is worth mentioning the results of social research report analysis. Analysing the cases, when staff indicated lack of progress, several particular reasons may be distinguished. In six cases staff indicated that inmate did not meet the criteria specified in the Paragraph 1 of Article 157 of the PEC (e. g. SRR7, SRR19, SRR10, SRR12) or the Paragraph 3 of Article 157 of the PEC (e. g. SRR8, SRR11) due to the moderate criminal risk and improper behavior during incarceration (i. e. having valid penalties). In all these cases inmates had some valid penalties. It is also worth mentioning that only one inmate had been rewarded for proper behavior during incarceration, while the other five inmates had never been rewarded during their sentence. So, in some social research reports the progress of risk reduction was perceived as proper behavior in correctional facility.

In the analysis of social research reports in which inmates' progress was viewed positively and they were predicted to comply with the law in the future, several variations of progress interpretation can be distinguished. First, in five cases specialists pointed out that inmates are trying to implement the measures set in rehabilitation plan. Also, in two cases the progress was based on participation in rehabilitation programs and proper behavior in correctional facility (e. g. positive conduct, being rewarded, complying with the rules set in correctional facility in SRR23).I In one case the progress was related to 21 point decrease of criminal risk score during the last assessment (the score dropped from 69 to 48 OASys points 
specifying that "the progress of risk reduction creates a presumption, that inmate shall comply with the law and shall not commit any crime"). Half of the inmates mentioned above did not have any penalties during their sentence; the rest had no valid penalties. Also, the majority of these inmates had been rewarded once or twice during their sentence. Additionally, in one case the inmate was classified as low-risk, while the other inmates were classified as moderate-risk. So, it may be concluded that the progress inmates make is often related to the implementation of measures set in rehabilitation plan and proper conduct in correctional facility (i. e. having no valid penalties and having been rewarded); also, it can be related to the decrease of criminal risk score. Still, it should be noted that specialists have rather different views of the progress of risk reduction.

The results of this study show that the progress of risk reduction is interpreted quite differently during all the stages of parole, as prison staff, parole board members and judges have variant positions regarding this concept. So it may be assumed that the progress made by the same person may be interpreted differently during separate parole stages. It is important to state that the definition of the progress of risk reduction presented in Article 157 of the PEC is quite obscure, so it might induce various interpretations of the progress made.

\subsection{INTENSIVE SUPERVISION}

In the course of the study we also inquired about the possible impact of the opportunity to apply parole earlier in cases in which the inmate accepts intensive supervision. ${ }^{16}$

Considering the impact of intensive supervision on the opportunity to apply for parole, parole board members named several advantages of this measure. First, inmates who accept intensive supervision may seek parole nine months earlier. The opportunity to apply intensive supervision facilitates parole decision-making, because paroled person is daily controlled and supervised (e. g. P6: "Fear might prevent him from making wrong decisions ... some limits are set, that person is supervised"; P4: "Intensive supervision actually means you can release that person easily"). Also, intensive supervision facilitates decision-making, because accepting intensive supervision proves that person is motivated to gain freedom and change his behavior. However, it should be noted that some parole board members thought intensive supervision has no impact on parole decision-making or sometimes even has negative effect (e. g. P7: "I think that intensive supervision is unnecessary, it

\footnotetext{
${ }^{16}$ According to the Paragraph 3 of Article 157 of the Lithuanian PEC, inmates, who have a right to request parole and accept intensive supervision, can submit their parole requests nine months prior to the date when they would have served the part of their sentence sufficient for parole request.
} 
causes a lot of difficulties. It is technically complicated, as we were told, the equipment runs only a certain radius. There was a case when a person went to his neighborhood and the equipment wasn't functioning anymore. Besides, it is expensive").

The analysis of data obtained during the survey of judges revealed that the opinion of judges on the application of intensive supervision was quite different. Some judges thought that intensive supervision is one of the measures to encourage the court to look at parole applications more often, because it helps to ensure stronger control of person's behavior released on parole (e.g., J2: "The intensive supervision is a very good thing, as it enables to control the person more, whilst he is in the medium, where he should be in his life otherwise, to adapt"). The opinion that the application of intensive supervision can, in some cases, promote the court not to apply the parole was also expressed since, according to the Probation Act, such supervision can be applied to the convict for no longer than for a year, and this period may, in some cases, be qualified by the judge as insufficient: J5: "Although the law does not provide for the direct assessment of that fact, however, the judge psychologically ... thinks about this. Yes, twelve were done, three are left, there is a match, but he can only be applied an intensive supervision. Or he would have the decision approved and would be waiting as long as the requirements of Article 75 of the Criminal Code point by point could be applied or intensive supervision, which can be extended by the probation service for up to a year at the maximum". The opinions of judges on the efficiency of intensive supervision were also different, since during the survey they also talked about the extremely high efficiency (e.g., J4: "As much as I took interest in this matter, the efficiency is even very high, and it really reaches even 99 percent - such figures were named ..."), but they also regretted considering the drawbacks of the efficiency of information about the intensive supervision. Thus, it can be concluded that the possibility of application of intensive supervision during the parole period is appreciated by judges ambiguously; the community of judges possibly does not have a united approach about when it would be appropriate to apply intensive supervision; there is no consensus on the effectiveness of the application of intensive supervision. One may assume that differences in the opinions of judges to intensive supervision shown during the survey can be one of the factors encouraging differences of case law in parole cases. 


\subsection{THE SIGNIFICANCE OF THE SOCIAL RESEARCH REPORT}

The main document based on which the members of the parole board and the court make a decision on a parole application is a social research report prepared by the specialists working in Social rehabilitation divisions and Psychological services of correctional institutions. Since the social research report provides the information on various areas of convict life (e.g., his criminal history, lifestyle and friends, thinking and behaviour, abuse of psychoactive substances, etc. $)^{17}$ it is the document that allows the parole board members and judges dealing with parolerelated issues to go deeper into the situation, behavior of convicts seeking for parole as well as possible changes during the sentence. Therefore, the study aimed at finding out how the parole board members and judges assess the social research report prepared in correctional institutions, their quality, how much weight was given to the information provided in these documents.

Most of the surveyed parole board members ( 5 out of 8 ) identified the social research report as significant and the main source of information when deciding on parole (e.g., P7: "Everything is summarized there, it is practically the main document"). It is noted that the social research report saves time, because all essential information on the convicted person is provided in a single document. However, it is important to draw attention to the fact that distrust of social research report has been expressed several times (e.g., P3: "Well, maybe, does not fully reflect the reality ..."; P4: "Well, not by one hundred percent, it seems sometimes that somehow does not match - we see one (the conversation with the convict during the parole board meeting - note of authors), and it is otherwise written in reports"). In addition, the parole board members mentioned that statements of the person during the parole board meeting are also important to them (e.g., P4: "When a man comes to the parole board and you clearly see whether his story is really stage-managed and whether it is actually true").

Most of the interviewed judges stated that the social research report and the information on the convicted person it provides plays quite a significant role in making a decision on the parole application (e.g., J6: "In fact, I attach much significance to the social research report, because, well, we lawyers are and ... we appreciate certain data, which are in the law. ... And the psychologists namely employ this social research report. They see deeper, they envisage the inside of man; they penetrate into his inner attitude. And I do not have any competence to do so ..."). Thus, the interviewed judges assessed the social research report as an

\footnotetext{
17 For more information see the Order of Minister of Justice of the Republic of Lithuania on the Approval of the Form of Social Research Report and Methodical Recommendations for the Preparation of Social Research Report, Official Gazette, 2012, no. 68-3500.
} 
informative, significant and useful document that helps to assess more reliably the tendency of convicted person to commit crimes repeatedly. It is also important to note that both judges and the parole board members welcomed the application of social research report when making a decision on release on parole, so the report should be deemed necessary tool during the parole hearing.

However, assessing the quality of social research report, the surveyed judges also identified several aspects for the improvement of this document. One of them is the lack of information on previous cases, where the convicted person applied for parole. According to the judges, if the social research report provided the information on the dates of previous submissions on release on parole, the estimation of criminal behavior risk of convicted person during earlier submissions would help to assess the progress made by a convicted person in reducing the criminal risk.

During the survey, the judges also expressed their opinion that the social research reports could lay more emphasis on changes in the thinking of convicted people; it is also important to specify how much the convicted person seeking parole is motivated to live without committing crimes, whether his motivation is internal or external: J6: "there is a lack of more comprehensive assessment of a psychologist. I would consider it so; it is even hard to describe. Current approach of a convicted person to the offense, what he did, his sincere regret, ... the psychologists know how to do this." J7: "... there should be something more motivated by the parole board, namely the progress should be reflected in the resolutions. Because the progress is very formal and very reiterated elementary. ... Do not make any violations, choose incentives, to take part in some sort of programs as much as possible, but nothing individual is apparent from the fact, no efforts of a person are visible." Therefore, the answers provided by the judges reveal that social research reports can lack the information about psychological changes, and the strength of motivation occurred during the imprisonment. In the examination of the methodical recommendations for the preparation of social research reports approved by the Minister of Justice of the Republic of Lithuania, it can be noted that three sections assessed by means of corresponding OASys methodology are attributed in this document for the assessment of psychological state, thinking, behavior and attitudes of the convicted person - 4.8. Emotional well-being; 4.9. Reasoning and behavior, and 4.10. Attitudes. In addition, the section 5.2. Participation in the correctional programs of conduct and its results can be associated with certain psychological changes. It is important to draw attention to the fact that the currently used form of social research report approved by the Minister of Justice does not provide the information about the peculiarities of the 
motivation of convicted person to live without committing a crime, since there is no separate section in the reports which could describe the motivation of convicted person to follow the law.

Summing up the legal factors of decision on the person's release on parole, it can be noted that during the process of the decision of the parole board on the parole application, the important role is played by the social research reports prepared by correctional institutions, the level of criminal behavior risk (and its decrease) of the person and the execution of the plan of social rehabilitation. According to the judges, parole should be applied to the convicted persons characterized by a low risk of repeated criminality. The judges do not rule out the possibility of parole application in case of a moderate risk of repeated criminality, but in this case the progress through the reduction of the risk of criminal behavior is assigned great importance during the decision-making process. Both the parole board members and judges can quite differently define the progress made by the convict, and rather vague wording of Paragraph 1 of Article 157 of the PEC can possibly affect the differences in the interpretation of existing progress. Different interpretations of parole board members and judges in relation to the assessment of the progress through the reduction of the risk may also encourage the observed differences of case law in parole cases, where the same criteria can be interpreted differently by different courts. Case law differences may also be promoted by the attitudes of one-too-many parole board members and judges to the application of intensive supervision during the parole.

\section{SUBJECTIVE FACTORS OF DECISION-MAKING ON THE RELEASE OF} A PERSON ON PAROLE

While dealing with the parole issues, the court should first follow the formal and material basis of parole application formulated in the PEC; considering the results of analysis of case law in parole application cases, the assumption that the decision of judges on parole may also be affected by other factors subjectively important to judges was raised. According to the research carried out by T.E. George and L. Esptein ${ }^{18}$ (1992), judicial decisions can be affected by both legal and extralegal factors. Having analysed the factors predicting judgments of the USA Supreme Court, we noted that the decisions were predicted by both the existing legal framework and internalized values of the judge, characteristics of the parties to legal proceedings and even certain political factors. The analysis of the decisionmaking process in parole cases by Lithuanian judges revealed that decisions of

18 Tracy E. George and Lee Epstein, "On the nature of Supreme Court decision making," American Political Science Review 86(2) (1992). 
judges on parole could be affected by many social and psychological characteristics of persons striving for parole. Since Lithuania has a two-stage system for release on parole from correctional institutions, the aim of the survey was also to ascertain subjective factors potentially affecting the decisions of parole board members.

\subsection{THE HISTORY OF CRIMINAL BEHAVIOUR OF THE CONVICT}

According to the majority of interviewed parole board members ( 6 out of 8 ), during the decision-taking process on the person's parole, the type and nature of committed crime are also important. For example, the parole board members are undisposed to apply parole to the persons convicted for organized and economic crimes (P6: "I think that for the crimes committed in an organized group and in particular those relating to the distribution of drugs, smuggling, crimes against the economy, the financial system, ... based on my belief, my appreciation and my experience, there are no random people there. The man, who had deliberately chosen that path, was engaged in it, practiced that activity and followed it. And very often will continue doing this after coming out"), distribution of drugs, violent crimes, murders and resonant crimes. Speaking about the significance of the crime committed during the decision-making process, the parole board members stress that the court also takes into account this factor. However, some surveyed parole board members state they understand that they should not assess the crime, but, according to them, it is quite difficult for them to get distance from that (e.g., P8: "The crime committed should not be assessed, the crime has already been assessed by the court and imposed certain sentence for it; but it sometimes works. If the crime is very serious, violent - it is particularly brutal if it was murder, rapes, and sometimes womanlike, many women in our board play out").

Most of the surveyed judges, when speaking about the criteria that must be taken into account during the decision-making process on the person's parole, mentioned such criteria as the number of previous convictions of person, the nature and severity of the last committed crime (e.g., J5: "Of course, the number of previous convictions. ... And, of course, another criterion is the severity of the crime"; J1: "At least I personally always look at this. Gravity and severity of the crime"). Hence, when deciding on parole application, the judges also tend to take into account the history of the criminal behavior of the convicted person. It is important to note that the history of criminal behavior of convict is taken into account when assessing the risk of his criminal behavior by OASys methodology and preparing the social research report. Therefore, the judges making decision on parole should not re-consider the history of criminal behavior of the person. 
Speaking about the criteria important for the decision on parole, some of the judges involved in the survey said that it is important to draw attention to the fact whether the convict seeking parole has previously been subjected to parole application from prison, and whether the convict did not violate the parole conditions: J2: "... this is a very important criterion to me that if he has already been released on parole, well, and if it is a serious crime, well, then I do not know, in this case we should look at it very cautiously". Therefore, when deciding on parole application, judges can show interest in whether the convict has already been subjected to parole application, and what the results were. This information is possibly a help to the judges when assessing the approach of convicted person to parole, responsibilities and limitations imposed during it, the propensity of convicted persons to follow the laws.

\subsection{BEHAVIOR OF THE CONVICT DURING THE EXECUTION OF PUNISHMENT}

The data of the survey revealed that the behavior of convicted person in prison for the absolute majority of the surveyed parole board members (7 out of 8 ) is a very important factor in making a decision on his parole (e.g., P4: "It is very significant, because he shows the attitude to order ipso facto"). According to survey participants, preferred behavior of the convicted person in prison or correctional institution includes benevolent relations with others (i.e. officers, other staff and inmates), attendance of social rehabilitation and correctional programs, payment of actions awarded by court and observance of procedures and rules (e.g., P6: "If he fails to follow the requirements of the regime here, then, perhaps, it can be expected minimally that he will follow them somewhere, too"), available incentives, learning and courtesy. During the interview, a large number of judges also stated that a decision on the parole application is affected by the behavior of the convict during the execution of punishment (e.g., J5: "... the behavior in correctional institution. Punished, unpunished, promoted, discouraged. If punished, then for what he was punished"), so this factor must be regarded as an important one during both stages of parole.

\subsection{THE PART OF UNEXECUTED PUNISHMENT OF THE CONVICT}

The analysis of the data showed that the part of unexecuted punishment is not important for the half of the surveyed parole board members when taking decision on the parole application (e.g., P5: "If he applied, he has the right"; P2: "We look in particular whether he has executed the necessary part"). Other 
respondents named this factor as very significant (especially when the person serves his sentence for a serious or very serious crime; e.g., P7: "It is terrible to release, when the larger part of punishment has not been executed yet; you do not look much at how long he has served his sentence, but you look at how much he has not served his sentence yet"). According to surveyed parole board members, the court takes into consideration the part of executed punishment of the convict (i.e. when the court adopts a decision not to apply the parole on the grounds of great part of unexecuted punishment, e.g., P8: "If we assess the work of parole board (the part of executed punishment - note of the authors), it does not really have some sort of influence, but considering the courts - it does have great influence"). Thus, based on our survey we can state that subsequent assessment and motives of judgments of courts by the parole boards potentially influence the decision of the parole board.

The judges who participated in the survey often argued that the part of unexecuted punishment of the convict also has some effect on the final decision on the parole application. Judges explained that if the convict had not executed the part of punishment imposed by the court, in some cases, the goals of punishment could not be achieved, the convict could make no conclusions about his mistakes, as well as the convict might be subject to the application of insufficiently long social rehabilitation, he might be unprepared to return to the society (e.g., J6: "Is, for example, ten years of social rehabilitation is enough to such behavior during the execution of punishment if he is sentenced, for example, to fifteen years of imprisonment for a serious offense. ... All this must be assessed. Maybe it is enough for one person, but maybe not enough for other; maybe he should stay longer"). Assessing this position of judges, it is important to raise the question whether in reality the execution of the entire custodial sentence imposed by the court can ensure a more effective social rehabilitation and re-socialization of the convict, or it is more effective to correct the behavior of the convict through the parole application. According to G. Sakalauskas, imprisonment should not be associated with an effective re-socialization of convicts, and often work counterproductively, and the program of integration into the society for convicts applied in Lithuanian prisons is applied only a few months before release from prison; thus, there is no purposeful work with the convicts during the entire period of imprisonment. ${ }^{19}$ In addition, the examination of the peculiarities of employment of convicts in prisons showed that in 2015 only 29.9 percent of imprisoned convicts

19 Gintautas Sakalauskas, "Kalinimo salygos ir kaliniu resocializacijos prielaidos" (Prison conditions and premises of prisoners' resocialization), Teisés problemos 2 (2015): 7. 
worked when serving their sentence. ${ }^{20}$ Since work activities in prison provides the inmates with the opportunity to gain work experience, not to lose working skills, the ability to work in prison should be regarded as one of the conditions of the most successful re-socialization and reintegration of convicts. Unfortunately, when serving the sentence, the opportunity for the person to work, to pay damages to victims of committed crime, and to solve existing social and psychological problems, are often limited. Therefore, it should be considered that, in order to reach much positive impact on the behavior of convicted persons, the priority should be given to parole and continuous work of probation services with the convicts released on parole rather than to the execution of entire punishment imposed by the court.

\subsection{COMPOSITION OF PAROLE BOARDS AND THE NUMBER OF BOARD} MEMBERS

When analysing the factors that may affect the decision on the person's parole, it also is important to discuss such criteria as the composition of the parole board and the number of members. When discussing the influence of the parole board on the decision regarding parole, according to many of surveyed parole board members ( 6 out of 8 ), the gender of parole board members does not affect the final decision (e.g., P4: "It seems to me that the common sense itself, perhaps, should dominate in both the men and women"). On the other hand, some parole board members noted that women are stricter (e.g., P3: "Women are stricter"), also pointed out that "men assess sexual offenders stricter" (P7).

The survey data revealed that the number of parole board members is significant for the final decision (e.g., P2: "May depend in some cases. For example, our board has two teachers, and when their students are discussed, they can provide a bit of support"; P6 "If there are more than a half of us, let's say, there are four of us out of seven, and there is no representative from the Prison Fellowship, there is no representative from religious organization, and only just - I ..., two officials from penitentiary are left, then our opinion would be still better in one way"). Some interviewed parole board members (3 out of 8) positively appreciate the fact that the parole board consists of not only the employees of correctional institutions, but also of representatives of other institutions. According to them, this enables a more detailed consideration of each case. In addition, attention is drawn to the fact that representatives from other institutions, according

20 Gintautas Sakalauskas, "Nuteistuju laisvès atèmimo bausme užimtumas: padètis ir galimybès" (Employment of imprisoned persons: current situation and opportunities), Teisés e-aktualijos 2 (8) (2015): 7. 
to survey participants, in some cases may even ensure the continuity of assistance to the released person (e.g., P4: "The part of society would come, let's say ... that if something shifts towards him. It seems to me that there should be not just the representatives of the parole board, well, I'd rather think, there could be somebody from a drug addicts' rehabilitation ..."). However, some participants of the survey stated that representatives from other institutions have less knowledge and information on the convicted person than the employees from correctional institutions, and essentially make their decision based on the conversation with the convict.

In sum, according to many parole board members, the part of executed punishment and the nature and character of the crime are not important for decision-making on the person's parole. However, some of surveyed parole board members think that it is difficult to ignore these factors, especially in cases of serious and violent crimes. Summarizing the information about subjective factors revealed during the survey that are likely to affect judicial decisions, it can be seen that, when considering parole cases, the judges may tend to take into account the history of criminal behavior of convicted persons, the behavior when serving their sentence and the part of unexecuted punishment. It is important to emphasize that, according to judges, the final decision on the parole application is determined not by following individual factors, but also the wholeness of the factors of previously heard legal decision-making and interaction. When making their decision, the judges invoke not only the basis of formal and material parole application indicated in PEC, but also other information on the convicted person provided in social research reports and personal file.

Comparing subjective factors revealed during the survey that may affect the decision on parole with the decision-making factors mentioned in the foreign studies, it could be seen that the foreign studies reveal the importance of both legal and other subjective factors of decision-making. For example, B. M. Huebner and T. S. Bynum's study ${ }^{21}$ revealed that, when taking decision on the parole of sex offenders, the assessment results of criminal behavior risk score great importance, demographic characteristics of convicted persons, the age of crime victim, as well as the gravity of the offense and the behavior of the convict during the execution of punishment. The research by K. D. Morgan and B. Smith showed ${ }^{22}$ that the decision on the parole application can be predicted by such factors as the gravity of the offense committed by the convict, the part of executed punishment, the number of

\footnotetext{
${ }^{21}$ Beth M. Huebner and Timothy S. Bynum, "An analysis of parole decision making using a sample of sex offenders: A focal concerns perspective," Criminology 44(4) (2006): 979.

22 Kathryn D. Morgan and Brent Smith, "The impact of race on parole decision-making," Justice Quarterly 25 (2) (2008): 429.
} 
disciplinary sanctions and recommendations of the penitentiary officer, who worked with the convict, on possibilities of parole application. Results of research carried out by Sh. Danziger et al. showed ${ }^{23}$ that, when considering parole issue, the judges were less likely to apply the parole to convicted persons prone to recidivism and the convicts, who were not subject to the application of rehabilitation program. The importance of criminal histories of convicts and their behavior, when serving their sentence, for taking decision on parole, has also been emphasized in a study conducted by J. L. Proctor in 1999. The results of this survey showed that the decision on the parole is predicted significantly by the involvement of the convict in social rehabilitation programs, recommendations of the staff from correctional institutions for further re-socialization of the person, the number of previous convictions and the seriousness of the last crime committed ${ }^{24}$. Thus, the importance of the factors possibly having influence of the decision-making on parole for the judges and parole board members considering this issue revealed during the study was also noticed when examining the practice of foreign countries related to the parole application. Like foreign research results, the results of this survey show that when making a decision on the parole application it is difficult to distance oneself from the information characterizing the convict presented in the personal file and the findings of social study, and thus to follow only legal criteria.

\section{OTHER FACTORS THAT MAY AFFECT JUDGES' DECISIONS ON}

\section{PAROLE}

Although Article 3 of the Law on Courts of the Republic of Lithuania addresses the independence of judges and states that judges may not be exposed to any political, economic, psychological or social pressure ${ }^{25}$, the survey aimed at finding out whether the decisions of judges on the parole application may be affected by the role of other trial participants (e.g., counsel, prosecutor), position on parole application expressed by parole boards, media attention.

\subsection{ROLE OF COUNSEL}

Speaking about the role of the counsel of the convict in parole cases, the judges argued that mostly the counsels do not participate in such kind of cases (e.g., J3: "And the counsels at all ... They are not present"; J1 "For at least they do

23 Shai Danziger, Jonathan Levav, and Liora Avnam-Pesso, "Extraneous factors in judicial decisions," Proceedings of the National Academy of Sciences 108 (17) (April 2011) // DOI: $10.1073 /$ pnas. 1018033108.

24 John L. Proctor, "The 'new parole': An analysis of parole board decision making as a function of eligibility," Journal of Crime \& Justice 22 (2) (1999): 211.

${ }^{25}$ Law on Courts of the Republic of Lithuania, Official Gazette (1994, no. 46-851). 
not absolutely participate during the trial. They do not give their opinion nor any requests, absolutely nothing"). Therefore, based on the answers provided by judges, it is possible to assume that the convicts seeking parole can often not have counsel during trial proceedings. According to the Article 360 of the Lithuanian Code of Criminal Procedure ${ }^{26}$, the participation of the counsel in parole cases is not mandatory, and the information about the upcoming hearing is given to the convicted person and the prosecutor. Still, Paragraph 6 of Article 164 of PEC indicates that one of the person who has the right to submit a complaint against the decision of the parole boardis a defender of the convict, but mandatory participation of the defender of the convict in parole process is not embedded in PEC as well. One may assume that it can be difficult for convicted persons in prison to find a lawyer to represent the interests of the convict when considering the question of parole application due to the lack of resources and limited possibility of liaising with the people outside. Thus, the interests of currently convicted people seeking parole may not be defended sufficiently during the trial.

\subsection{ROLE OF PROSECUTOR}

When asked about the prosecutor's role in parole cases, the judges argued that after the wording of Article 360 of the Lithuanian Code of Criminal Procedure was changed on 1 September 2015, the prosecutors no longer have to provide their response on the decision taken by the Parole board, and therefore, the prosecutor's role in parole cases has decreased recently (e.g., J3: "Unfortunately, the prosecutor's office seldom provides its response and generally expresses its position relating to this issue very rarely recently"). However, the part of the judges involved in the survey said that prosecutors express their position on the parole application in cases, where they disagree with the parole application: J6: "... now we see only in the event if before, but we even do not know why in other cases he is not against it". Thus, it can be assumed that the prosecutor's role in parole cases recently has become smaller; the prosecutors often express their opinion when they disagree with parole application, but they are potentially more active participants in court proceedings on parole cases than the counsels of convicted persons.

\subsection{ROLE OF tHe pOsition OF PAROLE BOARD ON PAROLE} APPLICATION

According to Paragraph 4 of Article 164 of PEC, the district court in the location where the prison of the convict is, must always be sent the decision of

${ }^{26}$ Code of Criminal Procedure of the Republic of Lithuania, Official Gazette (2002, no. 37-1341). 
parole board on the parole application or non-application as well as personal file of convicted person. Therefore, dealing with parole-related issues, the judges always have a certain "reference point" - the position of parole board. Speaking about the importance of the decision adopted by the parole board to the final judgment, the part of the judges involved in the study argued that the parole board's position is a significant factor in the decision-making process: J5: "... if you see that the parole board proposes a man, well, yes, that is one of levers"; J6: "It's a very big role. Because, well, I take it so that the society comes and says, 'we take him with us', and asks the judge, 'do you agree?' This, according to my assessment, is a huge role". Some judges said that, despite the decision adopted by the parole board, they tend to re-evaluate all circumstances important for parole application: J7: "I have already said that we do not approve many decisions here, and thus the significance of decision adopted by the Parole board is not really decisive nor essential. Since we assess all material submitted". J1: "The court has to go deeper anyhow. And the board's, well, nothing has to be done, you just need to pick up and write the arguments". Thus, in some cases, the decision adopted by the parole board can somehow affect the judge's final judgment, but it may depend on how the judges assess the functions of parole boards, and how much responsibility they tend to assign to parole boards and courts.

The analysis of possible influence of the parole board and other participants of the process on the judgments of judges makes us take into consideration the anchor heuristics mentioned in the scientific literature examining the decisionmaking process. A. Tversky and D. Kahneman were the first to examine the manifestations of anchor heuristics in decision-making process. They described the anchor heuristics as the impact of starting point presented during the examination of particular problem on the final resolution to the problem ${ }^{27}$. It is important to note that anchor heuristics is often applied unconsciously, so the decision maker can rely on the "reference point" submitted to him without noticing its impact on the final decision. During the research examining the decisions of judges, it was found that the "anchor" presented during some of trials may affect the final decision of the judge on the size of custodial sentence ${ }^{28}$; additionally, the presentation of an "anchor" is associated with the size of recoverable property damage imposed by the jury $^{29}$. As for the results of this survey, it is possible to assume that, when deciding

27 Amos Tversky and Daniel Kahneman, "Judgement under uncertainty: Heuristics and biases," Science 185 (4157) (1974): 1128.

28 Thomas Mussweilerr, "Sentencing Under Uncertainty: Anchoring Effects in the Courtroom," Journal of Applied Social Psychology 31 (7) (2001); Birte Englich, Thomas Mussweiler and Fritz Strack, "The last word in court - a hidden disadvantage for the defense," Law and Human Behavior 29 (6) (2005): // DOI: $10.1007 /$ s10979-005-8380-7.

29 John Malouff and Nicola S. Schutte, "Shaping juror attitudes: Effects of requesting different damage amounts in personal injury trials," The Journal of Social Psychology 129 (4) (1989). 
on parole, the judges in some cases may also apply the anchor heuristics, because during the proceedings they may face with a number of "anchors" submitted to them - the opinion of the parole board and the prosecutor on parole application. It is important to note that based on the responses received from the judges the prosecutor's opinion on the parole application can often be negative. While the opinion of the counsel representing the interests of the convict in parole cases is often not expressed, the "anchor" favorable to the convict can often not be submitted to the judges. The following peculiarities of the information presented to judges and the positions expressed may encourage les the use of parole application from correctional institutions.

\subsection{ROLE OF MEDIA}

Although the judges who participated in the survey accentuated the independence of the court, it was also recognized that judges may suffer a certain pressure of media and biased presentation of their work in the media: J6: "This may, perhaps, of course, has an influence, ... like public opinion, I think, has affect in any other case. ... I am not saying that on procedural decisions or its result, but on person, taking decision in any case"; J2: "... we are all people, we read newspapers; we see the reaction of the media, as I said, to those cases, where a person commits a crime being on parole .... And we, too, are the part of society, and the influence from which we are trying to distance ourselves is considerable ...". Since the court is the institution in Lithuania that makes a final decision on the parole application, the attention of the media interested in certain parole cases can usually be directed to the judge that takes a decision. Moreover, the judges surveyed believe that the media can tend to emphasize unsuccessful cases of parole application from prison in which the inmates go on to commit crimes again. Thus, although the media attention and position expressed may not affect the final court decision on parole, due to the responsibility and the attention of the media, the judges taking a decision may feel some pressure from society in the form of the potential threat of criticism.

\subsection{PARTICULARITY OF PENITENTIARY}

Part of the surveyed judges said that the particularity of penitentiaries within their judicial territory could affect their approach to the convicts seeking parole (e.g., J7: "Maybe because the penitentiaries within the area of our activities are already for those, who are sentenced not for the first time. Then they are appropriate, the punishments are longer, stricter and, probably, the contingent is 
respectively different." J5: "Here we have murderers, rapists, robbers"). This circumstance named by the judges, which may be related to the final decision on parole, may be associated with the aforementioned tendency of judges to assess criminal history of the convict seeking parole. In addition, the particularity of penitentiaries and the convicts serving their sentence within the judicial territory may also affect the workload of judges as well as possibility of going deeper into the case of each person seeking parole. Thus, the particularity of penitentiary within their judicial territory named during the survey may affect the approach of judges to the convicts seeking parole, possibility to go deeper into the case of each person seeking parole due to the workload; additionally the particularity of penitentiaries within the judicial territory may also be associated with currently observed quite uneven judicial practice in parole cases.

In sum, the decisions of parole boards and, in some cases, the position expressed by prosecutors on the parole application, as well as the frequent absence of the counsel of the convict may affect the final decision of judges as certain "reference points". During the survey, the judges acknowledged that their decisions on parole application can sometimes be criticized and presented by the media exparte, and therefore, in some cases the judges make a decision on the parole application that is affected by certain pressures from the media and society. Finally, the decisions of judges on a parole application and uneven case law in parole cases may be associated with the particularities of penitentiaries within the judicial territory.

\section{CONCLUSIONS}

In the case of parole application, such legal criteria as the information on the convicted person provided in social research reports, the level of criminal risk of the person and implementation of social rehabilitation plan of the convict may play an important role.

The judges may be more willing to apply parole to the convicts characterized by low risk of criminal behavior, while the parole board members who participated in this study assess the parole application to medium risk convicts much more flexibly.

The progress made by the convict in reduction of the risk of criminal behavior is quite differently interpreted by judges and parole board members, so valid wording of Paragraph 1 of Article 157 of PEC possibly stimulates the differences in parole application practice not only in court, but also during the decision-making in parole boards. 
When making their decision on the parole application, both the parole board members and the judges who took part in the study tended to follow not only legal criteria, but also other information on the convicted person - e.g. his history of criminal behavior, the behavior during the sentence as well as the part of unexecuted punishment, etc. However, the surveyed parole board members assessed the part of executed punishment by the convict, and the nature of the crime, as less significant factors for the decision-making process.

Judicial decisions may be affected by the particularity of penitentiaries within their judicial territory, the opinion expressed by the parole board on the convicted person, a complaint submitted by the prosecutor concerning the parole application, as well as the rather passive role of counsels of the convicts seeking parole.

Because we chose a qualitative study design, it is important to remember that the conclusions of this study should primarily help get a deeper understanding of parole decision making process. Also, conclusions of this study could be used as possible directions for future quantitative studies of parole application in Lithuania.

Given the fact that during the examination of parole cases, the participation of public prosecutor is ensured, it is not intended to ensure the participation of the counsel defending the interests of convicted person. Thus it is advisable to consider a mandatory participation of the counsel in parole cases, when the appeal of the prosecutor against the parole application is received.

Currently Lithuania has a two-stage system for parole from correctional institutions, but the final decision on the parole application is always made by the court. The model of a two-stage parole hearing raises some doubts about both the parole board members and judges who were interviewed during this study. Since the parole board members can rely on a greater amount of information, and examples of foreign countries show that decisions on the parole application can be accepted by the parole board, we think that it would be appropriate to allow the parole boards to consider parole issues. The courts, then, could assess whether the parole boards followed the requirements formulated in the Regulations of the parole board on the parole from a correctional institution when making their decisions.

\section{BIBLIOGRAPHY}

1. Braun, Virginia, and Victoria Clarke. "Using thematic analysis in psychology." Qualitative research in psychology 3 (2) (2006): 77-101.

2. Danziger, Shai, Jonathan Levav, and Liora Avnam-Pesso. "Extraneous factors in judicial decisions." Proceedings of the National Academy of Sciences 108 (17) (April 2011): 6889-6892 // 
DOI: $10.1073 /$ pnas. 1018033108 .

3. Englich, Birte, Thomas Mussweiler, and Fritz Strack. "The last word in court a hidden disadvantage for the defense." Law and Human Behavior 29 (6) (2005): 705-722 // DOI: $10.1007 /$ s10979-005-8380-7.

4. George, Tracy E., and Lee Epstein. "On the nature of Supreme Court decision making." American Political Science Review 86 (2) (1992): 323-337.

5. Gobeil, Renée, and Ralph C. Serin. "Preliminary evidence of adaptive decision making techniques used by parole board members." International Journal of Forensic Mental Health 8.2 (September 2009): 97-104 //

DOI: $10.1080 / 14999010903199258$.

6. Huebner, Beth M., and Timothy S. Bynum. "An analysis of parole decision making using a sample of sex offenders: A focal concerns perspective." Criminology 44(4) (2006): 961-991.

7. Malouff, John, and Nicola S. Schutte. "Shaping juror attitudes: Effects of requesting different damage amounts in personal injury trials." The Journal of Social Psychology 129 (4) (1989): 491-497.

8. Morgan, Kathryn D., and Brent Smith. "The impact of race on parole decisionmaking." Justice Quarterly 25 (2) (2008): 411-435.

9. Mussweiler, Thomas. "Sentencing Under Uncertainty: Anchoring Effects in the Courtroom." Journal of Applied Social Psychology 31 (7) (2001): 1535-1551.

10. Proctor, John L. "The 'new parole': An analysis of Parole board decision making as a function of eligibility." Journal of Crime \& Justice 22 (2) (1999): 193-217.

11. Report of the Supervision Unit of the Prison Department under the Ministry of Justice of the Republic of Lithuania on Parole Process and Parole Boards' and Courts's Motives of Parole Declination in Year 2015. March $14^{\text {th }}, 2016$, no. LV948.

12. Sakalauskas, Gintautas. "Kalinimo salygos ir kaliniu resocializacijos prielaidos" (Prison conditions and premises of prisoners' resocialization). Teisés problemos 2 (2015): 5-53.

13. Sakalauskas, Gintautas. "Lygtinis paleidimas iš ikalinimo istaigu isigaliojus Probacijos istatymui: teorija ir praktika" (Parole application after the enactment of Probation act: theory and practice). Teisès problemos 4 (82) (2013): 5-39.

14. Sakalauskas, Gintautas. "Nuteistuju laisvès atėmimo bausme užimtumas: padètis ir galimybès" (Employment of imprisoned persons: current situation and opportunities). Teisès e-aktualijos 2 (8) (2015): 4-20. 
15. Tversky, Amos, and Daniel Kahneman. "Judgement under uncertainity: Heuristics and biases." Science 185 (4157) (1974): 1124-1131.

16. Vosyliūtè, Andželika. "Lygtinio paleidimo iš pataisos istaigu taikymo teismu praktikoje probleminiai aspektai" (Problematic aspects of parole application in court practice): 95-115. In: Gintaras Švedas, ed. Bausmiu vykdymo sistemos teisinis reguliavimas ir perspektyvos Lietuvos Respublikoje (Legal regulation and perspectives of penal system in Lithuania). Vilnius: Prison Department under the Ministry of Justice of the Republic of Lithuania, 2010.

\section{LEGAL REFERENCES}

1. Code of Criminal Procedure of the Republic of Lithuania. Official Gazette, 2002, no. 37-1341.

2. Law of Changes of the 11, 17, 18, 21, 25, 30 and 31 Articles of Probation Act of the Republic of Lithuania. Register of Legal Acts, 2015, no. 11079.

3. Law on Changes of the 18, 19, 66, 90, 91, 126, 138, 140,152, 154, 157, $158,159,164,176$ Articles and invalidation of the 127, 160, 161, 162, 163, 179 Articles of Penal Enforcement Code of the Republic of Lithuania. Official Gazette, 2012, no. 4-110.

4. Law on Changes of the Penal Enforcement Code of the Republic of Lithuania. Register of Legal Acts, 2015, no. 11069.

5. Law on Courts of the Republic of Lithuania. Official Gazette, 1994, no. 46-851.

6. Order of Minister of Justice of the Republic of Lithuania No 1R-154 on Confirmation of Parole Boards Rules. Official Gazette, 2012, no. 65-3314.

7. Order of the Minister of Justice of the Republic of Lithuania on the Approval of the Form of Social Research Report and Methodical Recommendations for the Preparation of Social Research Report. Official Gazette, 2012, no. 68-3500.

8. Penal Enforcement Code of the Republic of Lithuania. Official Gazette, 2002, no. 73-3084.

9. Probation Act of the Republic of Lithuania. Official Gazette, 2012, no. 4-108. 